Predrag Vuković

Institute of Agricultural Economics, Belgrade
SCIENTIFIC REVIEW ARTICLE

DOI:10.5937/ekonomika1704053V

Received November, 20, 2017

Accepted: December, 12, 2017

\title{
CHARACTER AND DYNAMICS OF DEVELOPMENT RURAL TOURISM IN THE REPUBLIC OF SERBIA ${ }^{2}$
}

\begin{abstract}
The development of rural tourism has become a trend that is more or less present in almost all countries of Europe and North America today. In many countries it has enabled to resolve some of the important problems that burden life in the rural areas (unemployment, population migration to urban city centers, decrease of macroeconomic indicators, etc.). Its effect is synergistic, because it connects a large number of economic and non-economic activities and with its multiplied effects, has positive effects on local environment in which it develops.

Experiences that countries in which rural tourism is so far developed can contribute in practice in the Republic of Serbia which has significant potential for the development of rural tourism. They are reflected in preserved nature, developed agricultural production, prevalence of rural areas that covers more than $80 \%$ of the territory, rich anthropogenic heritage, geographical diversity of the territory that favors various forms of rural tourism, etc. Unfortunately, rural tourism has not gained importance in policy of economic development until recently.

The article analyzed the character and dynamics of the development of rural tourism in the Republic of Serbia and points to its phases of development. Also, it is given suggestions to facilitate monitoring and create preconditions for successful management.
\end{abstract}

Key words: rural tourism, development, destinations, accommodation

JEL classification: Q18, 011

\section{КАРАКТЕР И ДИНАМИКА РАЗВОЈА РУРАЛНОГ ТУРИЗМА У РЕПУБЛИЦИ СРБИЈИ}

\section{Сажетак}

Развој руралног туризма је данас постао тренд који је у већој или мањој мери присутан готово у свим земљама Европе и Северне Америке. Он је у великом броју земаља омогућио да се реше неки од важних проблема који оптерећују живот у руралним подручјима (незапосленост, миграције

\footnotetext{
${ }^{1}$ predrag_v@iep.bg.ac.rs

${ }^{2}$ Paper is a part of research within the project no. III 46006 - Sustainable agriculture and rural development in the function of accomplishing strategic objectives of the Republic of Serbia in the Danube region, financed by the Ministry of Education, Science and Technological Development of the Republic of Serbia. Project period: 2011-2014.
} 
становништва у урбане градске иентре, пад макроекономских показатеља итд.) Његово дејство је синергијско, јер повезује велики број привредних и ванпирвредних делатности и својим мултипликованим ефектима оставља позитивне ефекте на средину у којој се развија.

Искуства која имају земье у којима се рурални туризма до сада успешно развијао могу да послуже у пракси и у Репблици Србији која има значајне потенцијале за развој руралног туризма. Они се огледају у очуваној природи, развијеној пољопирведној производюи, руралном подручјукоје покрива више од 80\% територије, богатом антропогеном наслеђу, географском диверзитету територије који погодује различитим формама руралне туристичке понуде, итд. Нажалост, до недавно рурални туризам није добио на значају.

У раду се анализира карактер и диниамика развоја руралног туризма у Репуличи Србији и указује се на његов досадашњи фазни развој. Такође, дају се сугестије са којима би био олакшан мониторинг и стварају претпоставке за успешана менаумент.

Kеу words: рурални туризам, развој, дестинација, смещтајни капащитети

\section{Introduction}

A certain number of authors (Lane 1994, Runte, 1990, Feifer, 1985) cite the $19^{\text {th }}$ century as a historical time point since it has begun developing rural tourism. Their need to specifing time point is primarily motivated by the number of tourists who from that time has begune visiting rural areas.

However, such a precise timeframe in terms of determining the start pint of rural tourism development should not be taken "strictly", especially, because people has gone for vocation and recreation in rural areas much earlier. Regarding this is witnessed by many facilities that were built and used for the purpose of their vocation, and are present in large numbers there today. These are objects, such as summer houses, villas and objects for similar intentions. The countries that leading by the number of such facilities are United Kingdom, Germany, Switzerland, Austria, France, Russia, etc. (Vuković at al. 2010).

Rural tourism started to develop in the Republic of Serbia in seventies of twentieth century. Until now it has various intensivity, character and dynamics.

\section{Material and method}

The subject of article is the character and dinamics for development of rural tourism in the the Republic of Serbia. The aim is to point out the actual situation and potentials for further strategic directions for the future development of rural tourist destination in the context of sustainable development. In this way, obviously great potential for further development of tourism would be practical sense realised. Former policy undifferentiated marketing did not give results. The strategy of market focus, integrated marketing, with a clear specifying tourism aspects, with the consistent implementation of the basis on which should insist in future development. Methods that used in this paper are: inductivedeductive method, qualitative method, comparative method. 


\section{Result and discussion}

Rural areas with the preserved nature and tradition of different rural areas have always attracted people to stay and vocation. More recently, the interest of people for vocation in rural areas has increased, primarily due to problems which are present in urban centres such as environmental pollution, increasing alienation from the natural environment, uniformity and standardization offered by modern lifestyles in urban urban areas, etc.

Increase of interest for rural tourism is first recorded in countries of western Europe, then in North America and afther that in other countires of central and eastern Europe. In Republic of Serbia rising interest for rural tourism vocation began to be recorded in seventies of the twentieth century.

Accepting attitudes about the phase development of rural tourism with the corresponding characteristics introduced by Zodorov, A. V., (2009), it can be concluded that in the Republic of Serbia, as in most other countries, rural tourism has developed in an identical manner with the same features, even the duration of the phases can be precisely determined.

The first phase of an independent establishing. Rural tourism in Serbia has started to develop since the seventies of the twentieth century. The villages that were so called The "pioneers" of the development are Sirogojno, Seča Reka and Devići. At that time, the leading tourist agencies "Yugoturs" and "Putnik" were involved in the business of bringing foreign tourists to rural areas. Thus, according to the 1992 Serbian Tourist Association, in the Knić municipality there were about 35,000 foreign tourists from 21 countries. The largest number of tourists was recorded from Great Britain, Germany, Russia and Italy. (Todorivić, M. \& Bjelac, Ž., 2009; Milojević, Lj., 2004, etc.)

Municipalities in which rural tourism developed successfully until 2000 were Brus, Valjevo, Gornji Milanovac, Ivanjica, Knić, Kosjerić, Kraljevo, Lučani, Mionica, Požega, Prijepolje, Rača Kragujevac, Sokobanja, Užice, Čajetina, Čačak and Šabac. Indicators of the development of rural tourism are illustrated in Table 15.

Table 1. Indicators in the development of rural tourism in Serbia in the period 1990 2000 according to the data of the Tourist Organization of Serbia (TOS)

\begin{tabular}{|l|c|c|}
\hline \multicolumn{1}{|c|}{ Year } & 1990 & 2000 \\
\hline Nomber of villages & 50 & 41 \\
\hline Nomber of Households & 800 & 170 \\
\hline Nomber of beds & 3000 & 800 \\
\hline
\end{tabular}

Source: Milojević, Lj., (2004): „,Rural Tourism in Serbia“, p.30, UNWTO: „,Rural Tourism in Europe: Experiences, Development and Perspectives", p. 27 -31, Proceeding from Seminars, Belgrade (Serbia and Montenegro, 24-25 June 2002), Kielce (Poland, 06-07 June 2003), Yaremcha (Ukraine, 25-26 Sept. 2003) published by UNWTO 2004. Web link: http:// www.idestur.org.br/download/20120219145557.pdf (access 14.01.2017.)

The reasons for the occurrence of negative trends in the development of rural tourism in the observed decade should be seen primarily in the deep political, social and economic crisis that reflected on all segments of the society and hence on tourism. 
The strengths in the development of rural tourism relate to: preserved and numerous natural resources, rich cultural and historical heritage, the number and diligence of rural settlements, the richness of local traditions, traditional hospitality, diversification of the tourist product. Disadvantages are: inadequate rural infrastructure, "archaic" tourism product, underdeveloped information system, unsatisfactory level of quality of mixing and other services, lack of training programs for farmers to provide adequate quality of services, lack of experience, lack of motivation, undeveloped awareness in rural areas economic and other benefits of rural tourism development.

The second phase, dedicated development started in 2006. Namely, at that time, the Ministry of Agriculture, Forestry and Water Management of the Republic of Serbia made decision to allocate in a total of 91580215 dinars for the development of rural tourism in the period from 2006 to 2008 and diversification of economic activities in the countryside ("Analysis of budget support to the development of rural tourism in Serbia and diversification economic activities in the countryside “, 2009, p.2). In 2008 there were 173 users of these funds (141 registered agricultural producers, 23 associations of citizens, 7 legal entities and 2 agricultural cooperatives). The largest amount of funds was distributed to the region of Western Serbia and AP Vojvodina, while most districts were distributed in Zlatibor district, and the least in the North Bačka District. The analysis of the types of investments indicates that as much as $91 \%$ of the funds allocated were directed to the restoration of traditional rural farms (adaptation, upgrading and renovation of buildings, procurement of equipment, etc.), while $9 \%$ were allocated for promotional and educational activities.

The number of villages and municipalities involved in rural tourism increased in 2009 (41 municipalities, 119 villages with 164 households with 570 rooms and 1628 beds). The main weaknesses in the development of rural tourism by 2009 are the nonorganization and the lack of networking between promoters of the tourist offer. (Štetić and Todorović, 2009, p.86.)

In 2011 two research papers were published by joint UN program in Serbia, titled "Sustainable Tourism for Rural Development", which was funded by the "Fund for achieving the Millennium Development Goals development initiative group(MDGIFSeCons".

- $\quad$ The first published by Đurović, D. and Cvejić, S., (2011), is a report compiled on the basis of a research conducted in four regions of the Republic of Serbia (Donje Podunavlje, Central Serbia, Eastern Serbia and South Banat). The full title of the document is "Rural tourism as a factor in rural development";

- The second is the "Master Plan for Sustainable Development of Rural Tourism in Serbia", which was made within the same program, which could be found on the official website of the Ministry of Finance and Economy of the Republic of Serbia until 2013.

According to the data presented in the Master Plan for Sustainable Rural Tourism Development in Serbia, which was compiled in cooperation with 106 local tourism organizations, rural tourism includes 2.7 million overnight stays, which is a sum of individual nights in rural tourism of $145354^{3}$ and the number of general tourist nights used

\footnotetext{
${ }^{3}$ These data are obtained by municipalities and LTOs. As this document highlights, "no central institution is in charge of collecting this data, except the Council of each municipality or LTO," p.15.
} 
for rural tourism of $2556128 .{ }^{4}$ Rural tourism provides more than 32,000 beds (registered and unregistered), with 10000 beds located exclusively in the village. The estimate is that the total number of beds annually brings more than 5 billion. RSD revenue and 5 billion. RSD direct revenues to the tourism sector. Revenue of 10 bln. RSD does not include visitors staying at least one night or staying with friends or relatives (although these persons spend on tourist and other accompanying services while staying) and does not include indirect contribution to the local economy in terms of income and employment. Revenue of 10 bln. RSD represents $16 \%$ of direct GDP from travel and tourism, as calculated by the "World Council for Travel and Tourism in Serbia" for 2010, which totals 62.4 billion. RSD. (Master Plan for Sustainable Development of Rural Tourism in Serbia, p.74-75).

Based on the comparison of data from both sources, it can be concluded that rural tourism is already an important factor in the development of tourism in the Republic of Serbia.

In document "the Strategy of development tourism in the Republic of Serbia Second Phase Report, Competitiveness Plan" (p. 94), it is anticipated that rural tourism in 2015 will comprise $6.6 \%$ of the total number of tourist nights, with an estimated market potential of one million overnight stays and the participation of foreign tourists from $15 \%$ of the total number of overnight stays, which makes about 150000 . However, practice has shown that the results were lower. In fact, due to the lack of a unique database of accommodation capacities of rural tourism, monitoring of the number of tourist arrivals and overnight stays was difficult. So, the real information about data still do not exist in 2017.

The weakness of existing accommodation capacities of rural tourism relate to (Đurović and Cvejić 2011, p.5-6):

- Undeveloped accommodation capacities and unsatisfactory quality of existing ones;

- Insufficient utilization of existing capacities;

- Incomplete offer of basic catering services;

- Economy of low volume and low prices;

- Insufficient additional services;

- Small investment capacity of households and slow development trend.

The problems that are burdened with the further development of rural tourism in Serbia are (Štetić and Todorović, 2009, p.88.)

- Insufficient education of interested rural households on how to accept and accommodate visitors / tourists;

- Insufficient number of tourist spots in the villages that deal with this type of tourism and poor connection with the municipal, regional and national tourist organization (TOS);

- Insufficient and inadequate social and road infrastructure.

Expansion in the development of rural tourism has experienced in the period 2009 - 2016, which can be traced through indirect sources of information that can be found on

${ }^{4}$ The "Master Plan ..." points out that "general tourist nights usable for rural tourism" means accommodation in rural areas, which can be used by tourists who visit the rural areas, but it is not called "rural households". 
Internet presentation of „Association of agroturism in Serbia“ on their offical web presention www.selo.rs that follow the accommodation capacities of rural tourism. It must be notice that this is not offical data because this association had data which distributed some of local tourst organizations in Serbia not all. It is not some kind of census accomodation facilities but only accomodation capacities which are include in that association. But, unfortunently this is only source of accomodation facilities which consitently monitoring number of accomodation units in the Republic of Serbia.

Table 2. Accommodation facilities by type in the Republic of Serbia which have Association of agrotuirsm in Serbia

\begin{tabular}{|l|c|l|c|}
\hline \multicolumn{1}{|c|}{ Type of acomodation } & Nomber of units & Type of acomodation & Nomber of units \\
\hline Apartment & 104 & Rooms & 17 \\
\hline Bed and breakfast & 5 & Rural Household & 90 \\
\hline Camp & 1 & Residente appartment & 2 \\
\hline Cottage & 26 & Tourist Complex & 3 \\
\hline Ethno Complex & 10 & Tourist facility & 19 \\
\hline Guest House & 45 & Villa & 31 \\
\hline Hostel & 1 & Wooden House & \\
\hline Hotel & 4 & & \\
\hline Motel & 1 & & \\
\hline
\end{tabular}

Source: Association of agrotuirsm in Serbia, www.selo.rs (accessed 17.11.2017)

\section{Conclusion}

Rural tourism since it has begune to develop in Serbia, went through two phases. The first one can be named independent establishing and second phase can be named dedicated development. The intensity, dynamics and character of the previous development were conditioned by a large number of factors (eg. the geographical location of the area, anthropogenic heritage, the degree of socio-economic development, the awareness of the local population about the importance that rural tourism has for the overall economic and socio-economic development of the rural area, etc.)

What appears as a need is the formation of a unified database of accommodation facilities rualnog tourism at the national level. "The Association of rural tourism in Serbia" has the most complete database of accommodation facilities of rural tourism so far. However, the problem is that it does not include all accommodation capacities of rural tourism and which owners of accommodation capacities do not have the obligation to be register in such a database. Hence, monitoring of the intensity, dynamics and character of development rural tourism has been hampered.

The geographical diversity of the Republic of Serbia provides the basis for further planning and actions in the development of rural tourism. In order to enter into the next phase of complex development of rural tourism, it is essential that the destination management of rural tourism is gaining importance at all levels from the local (mini rural tourist destination) to the regional and national level (macro rural tourist destination). In second case, entire rural areas are regarded as potential rural tourist destinations. 
This approach makes it easy to apply marketing and management techniques to managing rural destinations. In this way, the basis for achieving positive results is created. In order to achieve this, it is necessary to form a destination management organization which would have a management function instead existing destination marketing organizations that have exclusively a promotional function. Destination management organization would inculde also promotional function.

\section{References}

„Analiza budžetske podrške razvoju seoskog turizma u Srbiji i diversifikacija ekonomskih aktivnosti na selu“ (2009), Ministarstvo poljoprivrede šumarstva i vodoprivrede Republike Srbije - sektor za ruralni razvoj.

Đurović, D., i Cvejić, S., (2011): „Ruralni turizam kao činilac ruralnog razvoja“, SeCons - grupa za razojnu inicijativu, Održivi turizam u funkciji ruralnog razvoja, zajednički porogram OUN u Srbiji, web link: http://www.secons.net/ admin/app/webroot/files/publications/SeConSizvestajruralniturizamsumarni.pdf (accessed 16.11.2017.)

Feifer, M., (1985): "Going Places: The Ways of the Tourist from Imperial Rome to the Present Day”, London, Macmillan;

Lane B., (1994), What is Rural Tourism, Journal of Sustainable Tourism, No. 1-2., Vol. 2;

Master plan for sustainable development of rural tourism in Serbia (2011), SeCons, UNDP, Ministry of finance and economy of the Republic of Serbia, web.link: http://futurehospitalityleaders.files.wordpress.com/2012/11/master-planodrzivograzvoja-ruralnog-turizma-u-srbiji.pdf

Milojević, Lj., (2004): „The Social and Cultural Aspects of Rural Tourism“, p. 117, UN WTO: „Rural Tourism in Europe: Experiences, Development and Perspectives“, p.115-121, Proceeding from Seminars, Belgrade (Serbia and Montenegro, 24-25 June 2002), Kielce (Poland, 06-07 June 2003), Yaremcha(Ukraine, 25-26 Sept. 2003) published by UNWTO. http://www.idestur.org.br/download/20120219145557.pdf(accessed 15.11.2017);

Runte, A., (1990): “Trains of Disvovery”, Niwot: Colorado, Rinehart Press

„Strategija razvoja turizma Republike Srbije“,Drugi fazni izveštaj,Plan konkurentnosti, (2006) str. 94. Ekonomski fakultet, Beograd i Horwath Consulting, Zagreb

Štetić, S. i Todorović, M., (2009): „Ruralni turizam“, Univerzitet u Beogradu, Geografski fakultet,

Todorivić, M. and Bjelac, Ž., (2009): „Rural tourism in Serbia as a Concept of Development in Undeveloped Regions“, p.455. journal: Acta Geographica Slovenica, 49-2. (2009), pp.453-473;

Vuković P., Arsić S. \& Cvijanović D., (2010), Konkurentnost ruralnih turističkih destinacija, Ekonomika poljoprivrede/Economic of Agriculture 57, Belgrade, br. 1(1-153) pp. 47-60.

Vuković, P., Kljajić, N., Roljević, S. (2009), Strateška opredeljenja razvoja turizma u procesu tranzicije u Srbiji “, Ekonomika br. 3-4. Niš, str. 168-177. 
Zdorov, A. B., (2009): „Comprehensive Development of Tourism in the Countryside“, Studies on Russian Economic Development, 2009, Vol. 20, No. 4, p. 453-455. (C) Pleiades Publishing, Ltd., 2009, Original Russian Text; 